УДК 159.9:93

\title{
INSTITUTIONAL FACTORS IN THE DEVELOPMENT OF THE DOMESTIC HISTORY OF PSYCHOLOGY: AN ANALYSIS OF EVIDENCE FROM THE RSCI DATABASE ${ }^{1,2}$
}

\author{
(C) 2021 r. A. N. Morgun ${ }^{1, *}$, Yu. N. Oleinik ${ }^{2, * *}$, A. L. Zhuravlev , *** $^{*}$ \\ ${ }^{1}$ Federal State Autonomous Educational Institution of Higher Education \\ Pirogov Russian National Research Medical University Ministry of Health of Russia; \\ 117997, Moscow, st. Ostrovityanova, 1, Russia. \\ ${ }^{2}$ Autonomous Nonprofit Organization of Higher Education "Moscow University for the Humanities"; \\ 111395, Moscow, st. Yunosti, 5, Russia. \\ ${ }^{3}$ Federal State-Financed Establishment of Science, Institute of Psychology RAS; \\ 129366, Moscow, st. Yaroslavskaya, 13, building 1, Russia. \\ *Candidate of Psychological Sciences, associate professor, Department of Continuing Education Organization, \\ Faculty of Continuing Professional Education. \\ E-mail:an_morgun@mail.ru \\ ** Candidate of Psychological Sciences, head of the Department of General, \\ Social Psychology and the History of Psychology. \\ E-mail: yurii03@mail.ru \\ *** Member of RAS, scientific adviser, professor. \\ E-mail: alzhuravlev2018@yandex.ru
}

Paper received on March 26, 2020

\begin{abstract}
The article discusses bibliometric and scientometric indicators of an array of publications on the history of psychology, indexed by the Russian Science Citation Index (RSCI). The contribution of historical and psychological articles to formal indicators of the influence of scientific journals is shown. The organizations that make a significant contribution to the total number of historical and psychological publications are identified. The contribution of these organizations to formal indicators of the influence of the branch of the history of psychology as an array of publications indexed at the RSCI is also shown.
\end{abstract}

Keywords: history of psychology, H-index, impact factor, aggregate impact factor.

DOI: $10.31857 / \mathrm{S} 020595920014202-8$

Digitalization of the research results evaluation process dictates its own principles that change the configuration of academic trends. Prior to the era of global digitalization of learning the leading role in shaping the design of research belonged to academic journals, to the process of peer review in those journals and, accordingly, to the expert evaluation, which, in turn, was consistent with the editorial policy of the journal. Among the traditional criteria we can mention, for example, the importance attached to the novelty of

\footnotetext{
${ }^{1}$ The study is supported by the grant of the Russian Foundation for Basic Research 19-013-00779.

${ }^{2}$ This article is a translation of: Morgun A.N., Oleynik Yu.N., Zhuravlev A.L. Institutional factors in the development of the domestic history of psychology (on the material of the RSCI). Psikhologicheskii zhurnal. 2021. V. 42. № 1. P. 111-121. DOI: 10.31857/ S020595920013341-1.
}

academic knowledge (with scientific discovery as ultimate novelty).

The present time is permeated by information flows and communication in publication activity is growing in relevance and in demand. In various academic fields more attention is now paid to citation as a form of informational communication between publications even though until recently citation has not yet been the subject of attention of an author or a journal. Citation as an elementary form of big data, whose transformative role in the formation of the image of contemporary academic learning has been noted in modern research [11], is a fundamental principle of the formal assessment of academic performance. Citation means a link used by the author of the paper to any other publication, the contents of which is to some extent mentioned or described in the author's paper, the cited publication being 
included in the list of references of the author's paper [13]. Moreover, the number of links to a publication is a measure of its relevance. The interest of authors and journals in being included in information flows, which ensure the recognition and identification of a publication in the internet in real time makes the authors use the systems of the indexing of academic publications that dictate their own rules. For example, of the main criteria for the inclusion of a journal into international academic citation indices, the most important are the uniqueness of the specific academic field covered by the journal and the geographical diversity of its editorial board. Thus, the possibility of finding a publication in the global information space is of primary importance. In turn, the identification of publications in the information space and the formal assessment of information communication through citation generate a new aspect in the study of science: the influence (impact) of academic journals and academic fields expressed in the quantity of various publications. The influence of publication $\boldsymbol{a}$ (or their set $A$ ) is understood as the quantitative representation of references to it (or a set of them) in publications $b, b 1, b 2, \ldots b n$, which in turn indicates that publication $a$ (or their set $A$ ) influenced the course of the research or conclusions presented in publications $b, b 1, b 2, \ldots b n$. Any array of publications limited by a formal criterion (publications by one author, by a set group of authors, by an organization, thematic publications, publications within a certain time period, etc.) can be taken as the set of publications.

Consequently, academic citation indices are becoming more and more in demand: national (the Russian Science Citation Index in this country) as well as international such as the Web of Science information platform and the bibliometric and scientometric Scopus database.

Information and communication issues are actively discussed in academic discourse and in publications. The history of psychology as a branch of psychology, represented by a bulk of publications indexed in various information systems, is also an object of scientometric research. At present we note a specific theme in publications on psychology in general and on the history of psychology: the analysis of the degree of their representation in the academic information space or, specifically, in publications by Russian authors focusing on scientometric or bibliometric problems of psychology $[2,3]$ and the history of psychology [1, 4, 9-10, 14, 23], as well as by international authors [15-18, 20-22]. Historical and psychological approaches are being developed, associated with quantitative methods of analyzing the representation of the names of authors significant for the history of psychology in the information space [5-6], as well as the analysis of the representation of areas that are significant in the history of psychology [7-8].

Innovative scientometric tools and bibliometric resources that allow a formalized assessment of academic performance and academic communication provide new opportunities for researching science in general and in specific academic areas. This paper summarizes the results of a study undertaken in order to determine the degree in which the indicators of the influence (impact) of the history of psychology as an academic field depends on the impact it receives from academic organizations (social conditions of the science's existence). The object of the research is the aggregate array of publications on the history of psychology included in the Russian bibliographical database of academic publications - the Russian Science Citation Index (RSCI) of works by Russian scholars. The subject of the research is the contribution of institutional (external) factors to the formal indicators the influence of the publications on the history of psychology.

\section{METHOD}

The analysis was carried out using the national bibliographic database of academic publications by Russian scholars - the Russian Science Citation Index (RSCI).

The search for "history of psychology" in the RSCI finds 4774 publications. Search under the RSCI heading "15.01.09. History of Psychology. Personalities" detects 2221 publications without dissertations, reports and patents and 2293 publications with dissertations, reports and patents. Analysis of the detected array shows a high degree of error in the RSCI determining the contents of the headings. Thus, the rubric "history of psychology" includes works that can be called primary sources for psychology but have no relation to the history of psychology; rather, they must be recognized as historically important. For example, these are the works by S.L. Rubinstein, L.S. Vygotsky, Z. Freud and many others. Further exclusion of publications that are historically important but not related to the history of psychology allowed us to form a list with less than 1000 works on the history of psychology without dissertations.

The selection of publications on the history of psychology from the list was done using the profiles of the authors in the RSCI, and the selection from each author's profile of the publications on the history of psychology. This procedure made it possible to form a list for further consideration that included 2289 publications on the history of psychology, including books, 
papers in journals (1205 publications) and conference proceedings for the entire time of indexing in the RSCI.

The study used the methods of formal assessment of academic performance: the number of publications, the average number of citations per publication, the percentage of publications with non-zero citation, Hirsch index (h-index), two-year impact factor, weighted average impact factor and aggregated impact factor.

The average number of citations is determined by dividing the absolute number of detected links to publications (in our case) on the history of psychology by the total number of publications indexed in the RSCI on this topic.

The percentage of publications with non-zero citation represents the share of publications cited one or more times.

The Hirsch index (h-index) is a complex indicator of the productivity and influence of a given set of publications, expressed in the value of $h$, if $h$ publications of this set are cited at least $h$ (or $h \leqslant$ ) times each, and the rest of the set of publications $(N-h)$ cited less than $h$ (or $h \geqslant$ ) times each [19]. The index converts the number of citations into the number of publications in the estimated set allowing us to compare the influence of different sets of publications with a different number of publications in each of them.

The impact factor characterizes the ratio of the average number of citations received by a journal (or another given set of publications) in the estimated year to the number of publications in a given journal (or another given set of publications) for the two previous years [12, p. 83]. The impact factor is a dynamic measure of the impact of a journal measured annually, expressed as the average citation value per paper. The weighted average impact factor is an indicator of the average level of publications from a given set and is the ratio of the sum of the impact factors of the journal in which all papers from a given set were published to the number of papers from this set [ibid, p. 86]. To calculate the aggregated (collected) impact factor, a given set of publications is taken as a unified "metazine", for which the traditional two-year impact factor is calculated [ibid, p. 90]. The aggregated impact factor characterizes the average influence of a publication in a given set, accepted as a separate publication, publishing, for example, research materials on the topic of a given set (in this case, the history of psychology).

\section{RESULTS}

The bibliometric status of the history of psychology as an academic discipline, expressed by the indicators presented in Table 1 allows us to see the history of psychology as one of the influential branches in psychology.

As far as the average number of citations per publication (one of the most important indicators of demand) is concerned, history of psychology is second only to philosophical issues and methodology of psychology. This situation can be explained by the universality of the knowledge provided by the research in the history of psychology, as opposed to highly specialized areas. The indicator of the share of publications with non-zero citation is seen by the academic community as an argument for requesting the information represented in publications in the field of "history of psychology". In our case, $49.54 \%$ of cited publications prove the high

Table 1. Bibliometric Indicators of the Branches of Psychology (RSCI rubricators)

\begin{tabular}{|c|c|c|c|c|c|}
\hline № & $\begin{array}{l}\text { Branches of psychology } \\
\text { (rubricators of the RSCI) }\end{array}$ & $\begin{array}{l}\text { Number } \\
\text { of Publications }\end{array}$ & $\begin{array}{l}\text { of Papers } \\
\text { in Journals }\end{array}$ & $\begin{array}{c}\text { Average number } \\
\text { of citations } \\
\text { per article }\end{array}$ & $\begin{array}{c}\text { Percentage } \\
\text { of publications with } \\
\text { non-zero citation }\end{array}$ \\
\hline 1 & Personality psychology & 27122 & 15372 & 4.09 & 46.80 \\
\hline 2 & Psychophysiology & 20952 & 15450 & 3.48 & 57.60 \\
\hline 3 & Labor psychology & 9751 & 4950 & 4.18 & 48.72 \\
\hline 4 & Educational psychology & 12616 & 5691 & 3.27 & 40.74 \\
\hline 5 & Medical psychology & 9510 & 5790 & 2.88 & 46.15 \\
\hline 6 & Psychology of communication & 5651 & 2950 & 3.51 & 34.52 \\
\hline 7 & $\begin{array}{l}\text { Philosophical issues and methodolo- } \\
\text { gy of psychology }\end{array}$ & 1096 & 643 & 15.67 & 51.46 \\
\hline 8 & History of psychology & 2289 & 1205 & 5.75 & 49.54 \\
\hline 9 & Psychology of activity and behavior & 9264 & 6389 & 3.23 & 47.22 \\
\hline 10 & Ethnopsychology & 3569 & 2090 & 3.37 & 46.86 \\
\hline 11 & Psychology of management & 2183 & 1084 & 3.80 & 41.63 \\
\hline 12 & Pathopsychology & 5337 & 4342 & 2.42 & 52.22 \\
\hline 13 & Economic Psychology & 1938 & 971 & 3.29 & 52.63 \\
\hline 14 & Historical psychology & 786 & 642 & 2.53 & 52.54 \\
\hline
\end{tabular}


demand for this research in other academic fields. So, according to the percentage of the total number of references to publications on the history of psychology in journals of other academic fields (according to the thematic headings of the RSCI - the first 15 headings by the number of citations), the following distribution is found: Journals on: "Psychology" - 42.3\%, "Public education. Pedagogy" $-9.7 \%$, "Philosophy" $-4.6 \%$, "History. Historical Science" - 1.7\%, "Sociology" $1 \%$, "State and Law. Legal Sciences" - 0.9\%, "Linguistics" - 0.9\%," Economics. Economic Sciences" $0.8 \%$, "Medicine and Health Care" - 0.7\%, "Science of Science" - 0.4\%," Physical Culture and Sports" $0.4 \%$, "Culture. Cultural Studies" - 0.4\%, "Politics. Political Science" - 0.3\%, "Literature. Literary Studies. Folklore" $-0.3 \%$, "Biology" $-0.3 \%$.

Currently the Thematic Rubricator in the RSCI lists nine Russian journals entered in the rubricator 15.01.09. "History of Psychology. Personalities" of the National Rubricator of Scientific and Technical Information (SRSTI) (Table 2).

Of the nine journals listed in the heading, seven are multidisciplinary and only three journals have four or fewer headings in their list of sections, one of them being history of psychology, which allows us to regard these journals as the ones specialized in the history of psychology. These are the journals "Institut psihologii Rossijskoj akademii nauk. Chelovek i mir" /"Institute of Psychology of the Russian Academy of Sciences. Humans and the World " (5 issues, the last issue published in 2018, the RSCI rating and the two-year impact factor were not calculated); Metodologija i istorija psihologii" /"Methodology and History of Psychology" (23 issues, the last issue published in 2018, the last time the RSCI rating and the two-year impact factor was calculated in 2010-0.298); "Istorija rossijskoj psihologii v licah: Dajdzhest" /"The History of Russian Psychology in Persons: A Digest" (19 issues, the last issue published in 2018, the RSCI rating was not calculated, the two-year impact factor of 2018 is 0.352 ).

One would expect the main increase in publications on the history of psychology in the journals specifically focused on this topic, where it is not lost among many competing sections. To some extent, this is the case. However, due to their irregularity, these journals cannot provide the expected steady increase.

Distribution by journals publishing materials on the history of psychology allows us to identify the main core of periodicals specializing in this field. We may assume that the "Psihologicheskij zhurnal" / "Psychological Journal" of the Russian Academy of Sciences is the nuclear journal for the Russian history of psychology. According to the "law of scattering" of academic publications (Bradford's Law) formulated in the 1930s, the total number of publications in any field can be divided into three concentric circles, the first of which contains a small number of nuclear journals in this area, the second group contains a much larger number of journals in the fields related to the nuclear field, the third group includes a huge number of journals in which publications in this field are unlikely. This is confirmed by formal indicators, e.g. the average citation rate of academic publications (Table 3).

Table 2. Academic periodicals included under the heading "15.01.09. History of Psychology. Personalities" in the list of headings of the RSCI Thematic Rubricator

\begin{tabular}{|c|c|c|}
\hline № & Publication & $\begin{array}{l}\text { Number of Headings of the } \\
\text { RSCI Thematic Rubricator }\end{array}$ \\
\hline 1 & Psychology in Russia: state of the art & 36 \\
\hline 2 & Institut psihologii Rossijskoj akademii nauk. Chelovek i mir (bez ISSN) & \\
\hline & $\begin{array}{l}\text { Institute of Psychology of the Russian Academy of Sciences. The Humans and the } \\
\text { World (no ISSN) }\end{array}$ & 4 \\
\hline 3 & Istorija rossijskoj psihologii v licah: Dajdzhest & \\
\hline & History of Russian Psychology in Persons: a Digest & 3 \\
\hline 4 & Lichnost' v prostranstve i vremeni (bez ISSN) & \\
\hline & Personality in space and time (no ISSN) & 9 \\
\hline 5 & $\begin{array}{l}\text { Metodologija i istorija psihologii } \\
\text { Methodology and history of psychology }\end{array}$ & 2 \\
\hline 6 & $\begin{array}{l}\text { Professional'nye predstavlenija (bez ISSN) } \\
\text { Professional awareness (no ISSN) }\end{array}$ & 17 \\
\hline 7 & $\begin{array}{l}\text { Razvitie lichnosti } \\
\text { Personal development }\end{array}$ & 11 \\
\hline 8 & $\begin{array}{l}\text { Eksperimental'naja psihologija } \\
\text { Experimental psychology }\end{array}$ & 8 \\
\hline 9 & $\begin{array}{l}\text { Obrazovatel'nyj vestnik "Soznanie" } \\
\text { Educational bulletin "Consciousness" }\end{array}$ & 32 \\
\hline
\end{tabular}


Table 3. Indicators of the influence (impact) of journals that publish materials on the history of psychology, and the contribution of publications on the history of psychology to these indicators (first 15 positions)

\begin{tabular}{|c|c|c|c|c|}
\hline № & Journal & $\begin{array}{c}\text { Number of papers } \\
\text { on the history } \\
\text { of psychology } \\
\text { in 2016-2017 } \\
\end{array}$ & $\begin{array}{l}\text { Impact factor } \\
\text { of the journal } \\
\text { for two years } \\
\text { (RSCI, 2018) }\end{array}$ & $\begin{array}{l}\text { Average citation in } 2018 \\
\text { of publications on history } \\
\text { of psychology in } 2016 \\
\text { and } 2017 \\
\end{array}$ \\
\hline 1 & $\begin{array}{l}\text { Istorija rossijskoj psihologii v licah: Dajdzhest } \\
\text { History of Russian Psychology in Persons: Di- } \\
\text { gest } \\
\text { Jaroslavskii pedagogicheskii vestnik }\end{array}$ & 108 & 0.352 & 0.620 \\
\hline & Yaroslavl Pedagogical Bulletin & 18 & 0.399 & 1.647 \\
\hline 3 & Psihologicheskij zhurnal & 11 & 1.847 & 2.000 \\
\hline $\begin{array}{l}4 \\
5\end{array}$ & $\begin{array}{l}\text { Voprosy psihologii } \\
\text { Psychology } \\
\text { Institut psihologii Rossijskoj akademii nauk. } \\
\text { Social'naja i ekonomicheskaja psihologija } \\
\text { Institute of Psychology of the Russian Acade- } \\
\text { my of Sciences. Social and Economic Psychol- } \\
\text { ogy }\end{array}$ & 11 & 1.211 & 0.272 \\
\hline 6 & $\begin{array}{l}\text { Mir psihologii } \\
\text { The World of Psychology }\end{array}$ & 9 & 0.464 & 1.000 \\
\hline 7 & $\begin{array}{l}\text { Chelovecheskij faktor: Social'nyj psiholog } \\
\text { Human Factor: Social Psychologist }\end{array}$ & 8 & 0.122 & 0 \\
\hline 8 & $\begin{array}{l}\text { Sistemnaja psihologija i sociologija } \\
\text { Systems Psychology and Sociology }\end{array}$ & 8 & 0.362 & 0.625 \\
\hline 9 & $\begin{array}{l}\text { Jaroslavskij psihologicheskij vestnik } \\
\text { Yaroslavl Psychological Bulletin }\end{array}$ & 8 & 0.105 & 0 \\
\hline 10 & $\begin{array}{l}\text { Nacional'nyj psihologicheskij zhurnal } \\
\text { National Psychological Journal } \\
\text { Chelovecheskij faktor: problemy psihologii } \\
\text { i jergonomiki } \\
\text { Human Factor: Problems of Psychology and } \\
\text { Ergonomics }\end{array}$ & 7 & 1.071 & 0.714 \\
\hline 12 & $\begin{array}{l}\text { Razvitie lichnosti } \\
\text { Personal Development }\end{array}$ & 7 & 0.312 & 0 \\
\hline 13 & $\begin{array}{l}\text { Metodologija sovremennoj psihologii } \\
\text { Methodology of Modern Psychology }\end{array}$ & 5 & 0.079 & 0 \\
\hline 14 & $\begin{array}{l}\text { Kul'turno-istoricheskaja psihologija } \\
\text { Cultural \& Historical Psychology } \\
\text { Psihologicheskie issledovanija: elektronnyj } \\
\text { nauchnyj zhurnal } \\
\text { Psychological Research: an Electronic Journal }\end{array}$ & 4 & 1.034 & 1.500 \\
\hline
\end{tabular}

Table 3 shows the values of the impact factors of the journals that publish articles on the history of psychology and that are ranked by the number of such publications in 2016 and 2017, as well as the average citation of these papers in 2018. Thus, a comparison of the data of the two indicators of impact (of the journal for 2018 and of the publications on the history of psychology in these journals for 2018) makes it possible to assess the contribution of publications on the history of psychology to the indicator of the impact factor of the journal.

The contribution of publications on the history of psychology to the impact factor of the journals in which they are published is shown in Fig. 1.
If the average citation index of publications on the history of psychology of the impact factor of the journal is exceeded it marks a positive contribution of publications on the history of psychology to the impact factor of the journal; in the reverse situation we are witnessing a negative contribution to the impact factor (depletion of the impact factor). As is shown below, in 8 out of 15 cases publications in the history of psychology enrich the indicator of the journal's influence, in some cases significantly, e.g., for the "Jaroslavskij pedagogicheskij vestnik" or the "Institut psihologii RAN. Social'naja i ekonomicheskaja psihologija” journal. 


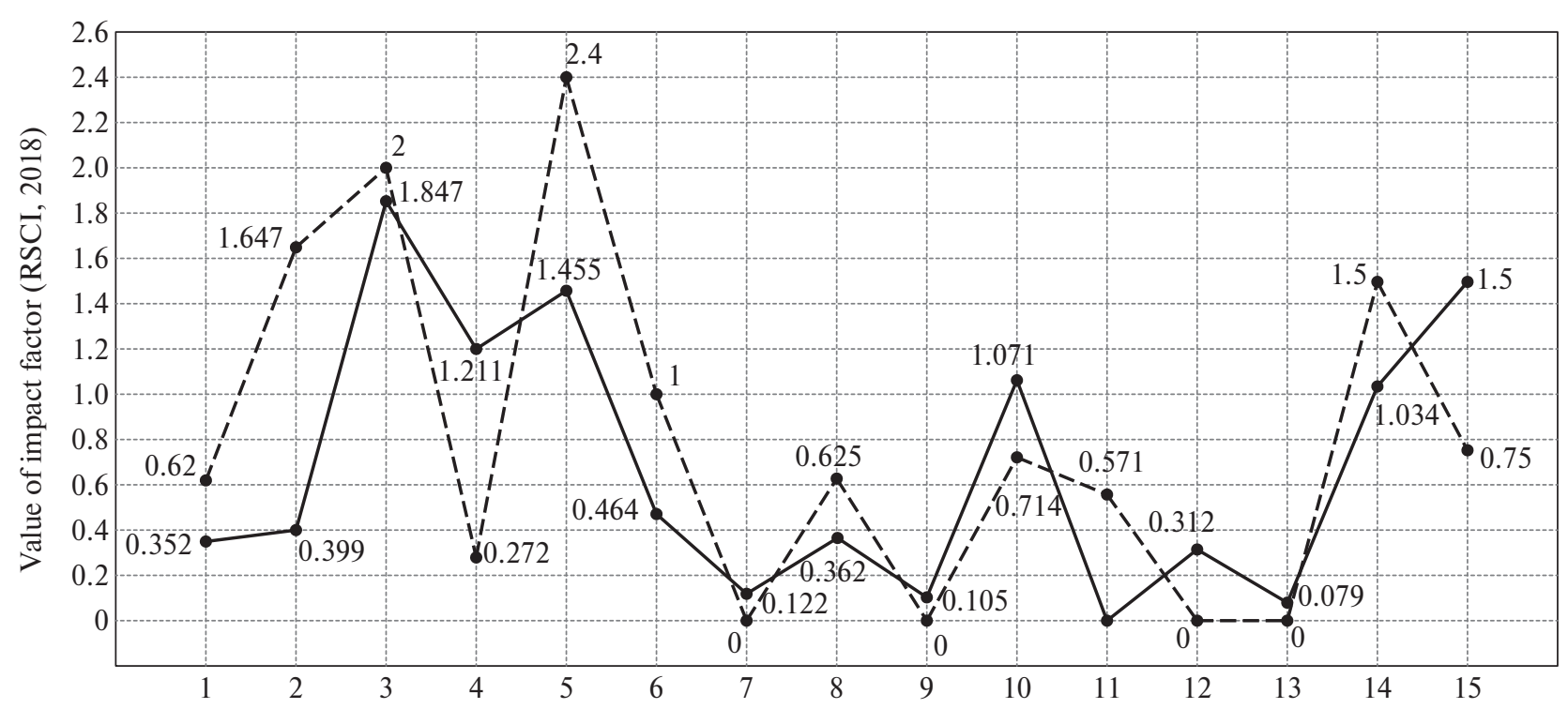

Fig. 1. Histograms of the impact factors of journals (2018, solid graph) publishing articles on the history of psychology, and the average citation rate (2018, dotted graph) of publications on the history of psychology (for the years 2016-2017) in these journals (see table 3)

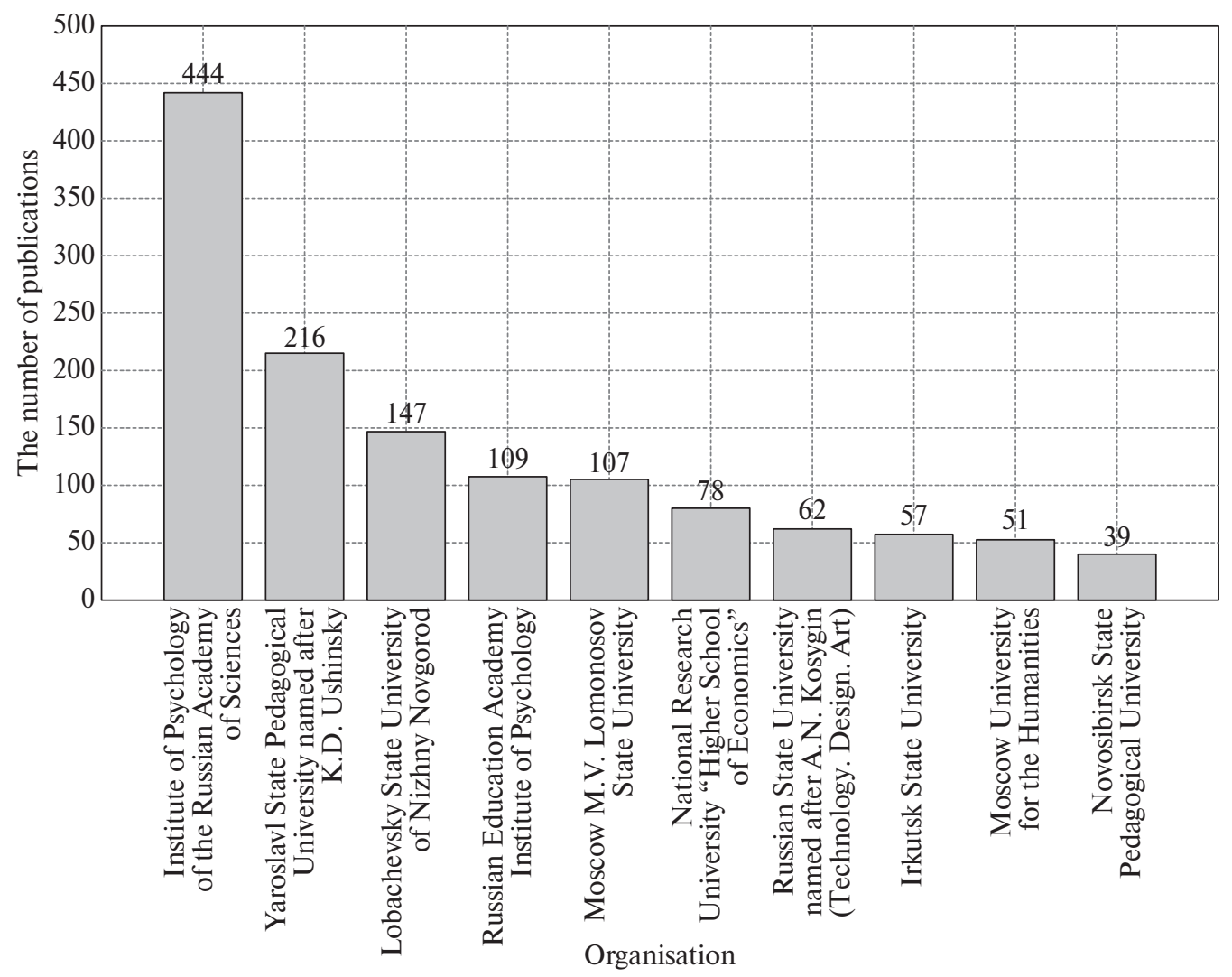

Fig. 2. Histogram of the distribution of the number of publications on the history of psychology by organizations (the first 10 organizations)

In Russia, as of December 2019, publication activity in the field of the history of psychology is supported in 212 research and educational organizations, 113 of which have at least two publications. For comparison, the top 10 organizations in the number of publications on the history of the psychology were selected (Fig. 2).
The absolute leader in productivity on the history of psychology is the Institute of Psychology of the Russian Academy of Sciences - 444 publications.

The " 35 " value of the Hirsch index in "History of Psychology" also makes the Institute of Psychology of the Russian Academy of Sciences the flagship in the 


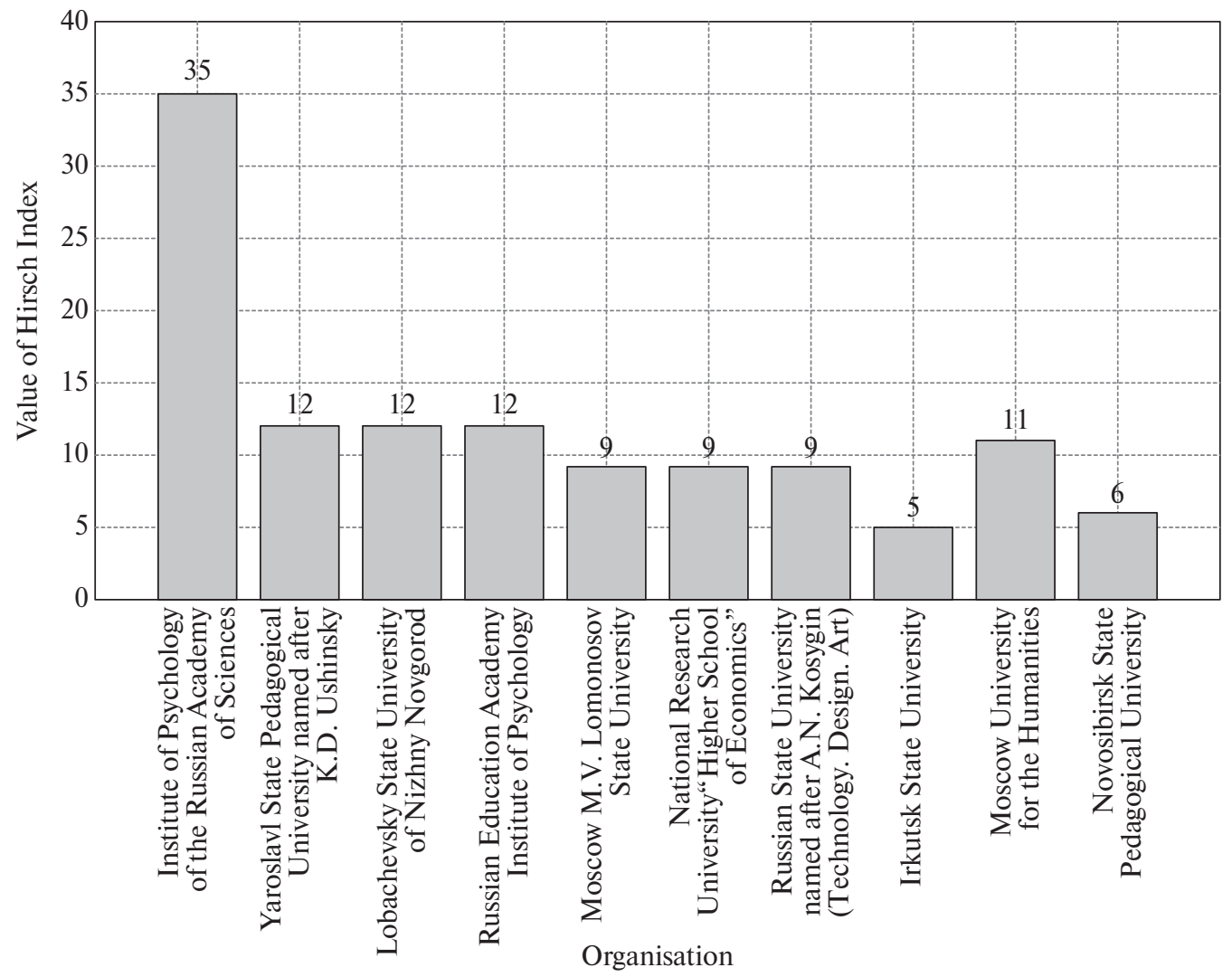

Fig.3. Histogram of the indicators of the Hirsch index of organizations in publications on the history of psychology (the first top 10 organizations)

field of the history of psychology (Fig. 3). The Institute of Psychology of the Russian Academy of Sciences is also distinguished by the fact that more than 20 employees of the organization participate in the increase in publications based on the results of the research in the history of psychology, while in other organizations of the top ten no more than 3or 4 authors contribute to the productivity of the organization in the field of the history of psychology and no more than 10 authors at Moscow M.V. Lomonosov State University.

To calculate the dynamic indicator of the influence of organizations in the history of psychology, the aggregated impact factor was calculated for the thematic array "history of psychology" for each year, starting from 2014 and ending in 2018. In Fig. 4 this aggregated impact factor is highlighted by the "area" graph. Also, two-year impact factors were calculated based on the publications on the history of psychology of the ten leading organizations in this indicator. We see that 10 leading organizations enrich the overall aggregate indicator of the influence of the academic field with their publications, mostly in 2017 and 2018. Among these organizations are the Institute of Psychology of the Russian Academy of Sciences, Yaroslavl State Pedagogical University, Nizhny Novgorod State Research University, Moscow University for the Humanities (MosGU).
To identify the level of influence of the "history of psychology" academic field, represented by publications on the history of psychology indexed in the RSCI, we compared the indicators of the aggregated impact factor of the array of publications on the history of psychology with the impact factor indicators based on the median of psychological journals indexed in the RSCI.

The histogram demonstrates a significant excess of the indicators of the aggregated impact factor of the array of publications on the history of psychology in relation to the median value of the impact factor of psychological journals, which indicates the high influence of works in the history of psychology in the publication space of psychology of the Russian Science Citation Index. Table 4 demonstrates the indicators of the rank value of a journal on psychology in the RSCI from 2014 to 2018, corresponding to the aggregated impact factor of publications on the history of psychology. Obviously, the aggregated value of the impact factor of the publication arrays in consideration, taken in accordance with the rank of the psychology journal, invariably localizes them in the first quarter by influence of the entire rating list of psychology journals indexed in the RSCI. 


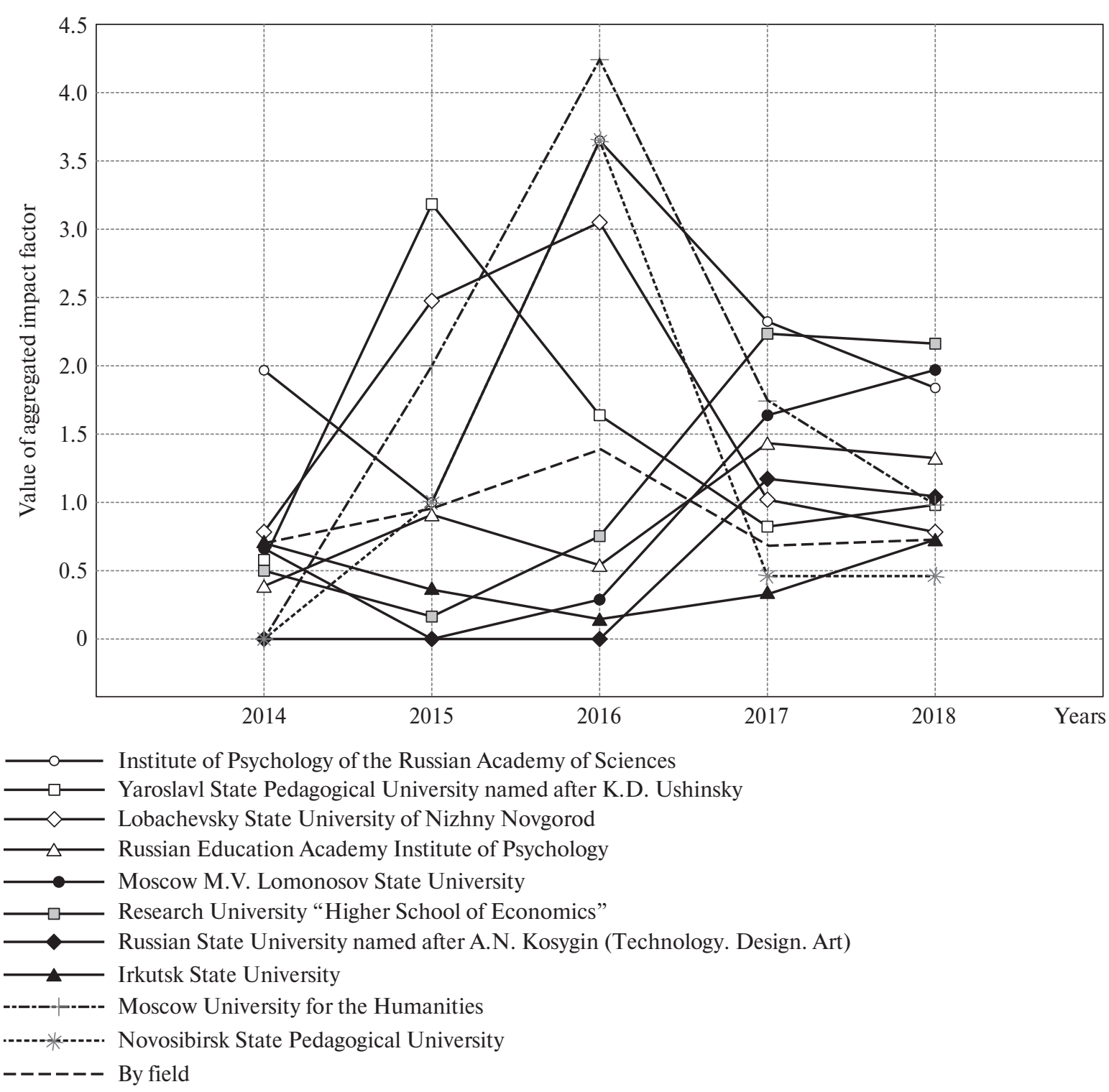

Fig 4. Profiles of the aggregated impact factor (two-year) of organizations publications on the history of psychology from 2014 to 2018

\section{CONCLUSIONS}

As a result of the bibliometric analysis of the RSCI publication array in the topic "history of psychology", it was found that:

1. The history of psychology as a subject of bibliometric analysis in terms of its formalized indicators of academic performance occupies one of the leading places in the academic field of psychology: a position above the medial, which indicates a high demand for this academic discipline.

2. As a result of the bibliometric analysis of publication activity in the history of psychology, institutional leaders have been identified that form the main features of the history of psychology as an academic field in Russia; absolute leadership in this respect is held by the
Institute of Psychology of the Russian Academy of Sciences.

3. The projected positive increase in publications per year provided by specialized journals on the history of psychology is not confirmed. The main reasons for this are: the placement of papers on the history of psychology in multidisciplinary journals; irregular publication of specialized journals on the history of psychology; authors do not use general, appropriate area labelling for academic publications (at least as far as titles and keywords are concerned).

4. The influence (impact) of multidisciplinary psychological journals in the RSCI system is closely related to the impact of the authors' publications in the "history of psychology" field. 


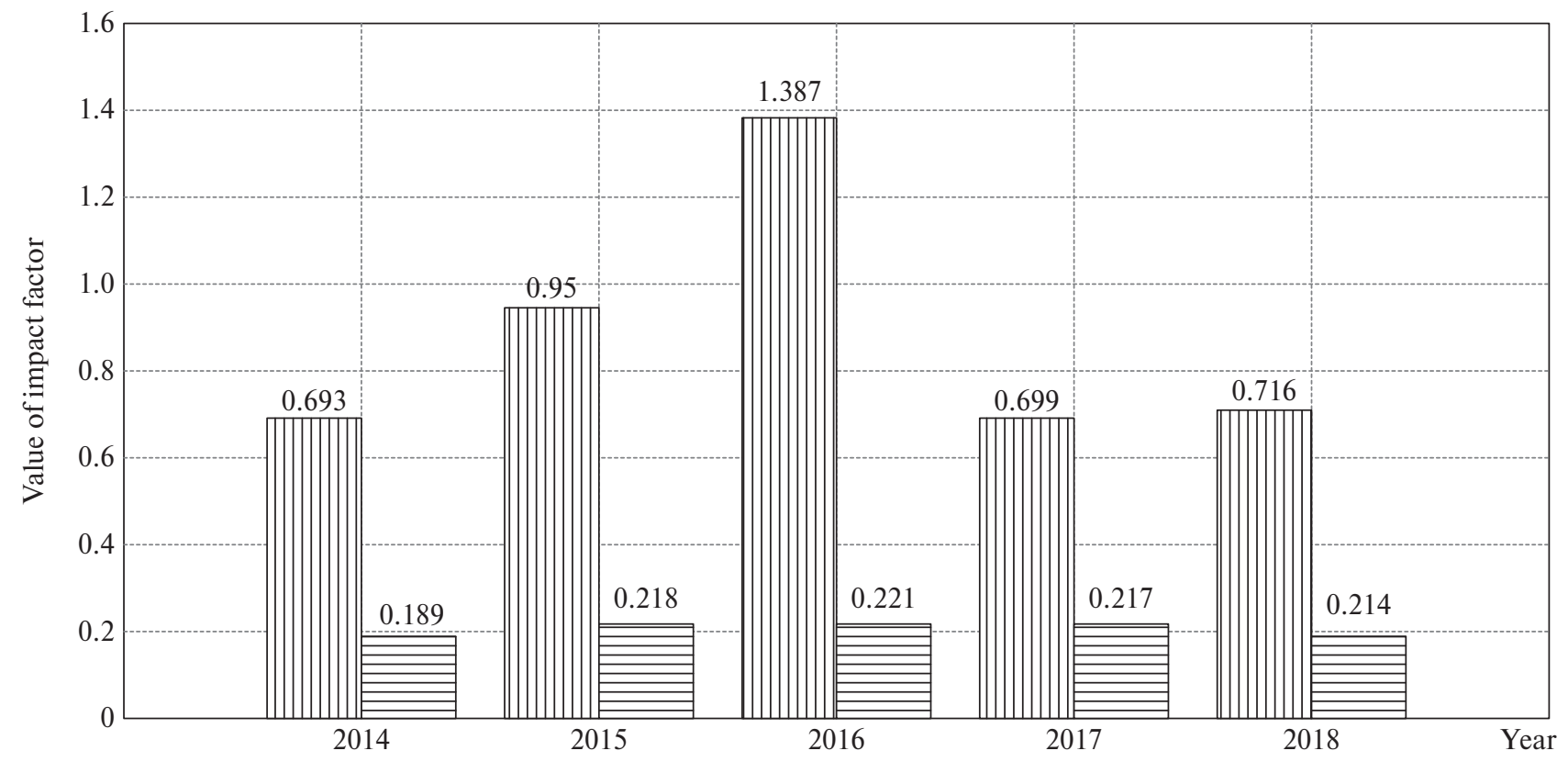

Fig. 5. Histogram of indicators of the aggregated impact factor of an array of publications on the history of psychology (histograms with vertical shading) and impact factor indicators by the median of psychology journals (histograms with horizontal shading) (RSCI)

Table 4. Approximate indicators of the rank of a journal on psychology in the RSCI, corresponding to the aggregate impact factor of the "meta-journal" "History of Psychology" (by years)

\begin{tabular}{c|c|c|c}
\hline Year & $\begin{array}{c}\text { Aggregated impact factor } \\
\text { of an array of publications } \\
\text { on the history of psychology }\end{array}$ & $\begin{array}{c}\text { The rank of the journal } \\
\text { in the RSCI, corresponding } \\
\text { to the aggregated IF on the history } \\
\text { of psychology }\end{array}$ & $\begin{array}{c}\text { Total number of journals } \\
\text { on psychology in the RSCI }\end{array}$ \\
\hline 2014 & 0.693 & 31 & 289 \\
2015 & 0.95 & 15 & 313 \\
2016 & 1.387 & 9 & 347 \\
2017 & 0.699 & 39 & 359 \\
\hline
\end{tabular}

5. The history of psychology is identified as a "metajournal" (in terms of the aggregate impact factor) in the first most influential quarter of the entire rating list of psychological journals indexed in the RSCI.

\section{REFERENCES}

1. Eliseeva I.N., Olejnik Ju.N. Naukometricheskij analiz kak metod izuchenija sostojanija i dinamiki nauchnogo napravlenija (na primere ispol'zovanija kategorii "individual'nost"” v nazvanijah dissertacionnyh issledovanij 1992-2018 gg.) // Metodologija, teorija, istorija psihologii lichnosti / Otv. red. A.L. Zhuravlev, E.A. Nikitina, N.E. Harlamenkova. M.: Izd-vo "Institut psihologii RAN”, 2019. S. 218-233 [Eliseeva I.N, Oleinik Yu.N. Scientometric Analysis as a Method for Studying the State and the Dynamics of an Academic Branch (on the material of using the category "individuality" in the names of dissertation research topics in 1992-2018) // Methodology, Theory, History of Personality Psychology / Eds. A.L. Zhuravlev, E.A. Nikitina, N.E. Kharlamenkov. M.: "Institute of Psychology of RAS", 2019. P. 218-233.]
2. Zuev K.B., Nestik T.A. Bibliometricheskij analiz osnovnyh pokazatelej publikacij po teme "Psihologija" v naukometricheskoj baze Web of Science Core Collection // Fundamental'nye i prikladnye issledovanija sovremennoj psihologii / Otv. red. A.L. Zhuravlev, V.A. Kol'cova. M.: Izd-vo "Institut psihologii RAN", 2017. S. 18221829 [Zuev K.B., Nestik T.A. Bibliometric Analysis of the Main Indicators of Publications on the Topic "Psychology" in the Scientometric Database Web of Science Core Collection // Fundamental and Applied Research in Modern Psychology / Ed. A.L. Zhuravlev, V.A. Koltsov. M.: "Institute of Psychology RAS", 2017. P. 1822-1829]

3. Zuev K.B., Nestik T.A. Bibliometricheskij analiz razvitija osnovnyh napravlenij psihologicheskih issledovanij (po dannym WoS i statistike poiskovyh zaprosov Google) // Psihologicheskoe znanie: sovremennoe sostojanie i perspektivy razvitija. M.: Izd-vo "Institut psihologii RAN", 2018. S. 671-697 [Zuev K.B., Nestik T.A. Bibliometric Analysis of the Development of the Main Directions of Psychological Research (according to WoS data and statistics of Google search queries) // Psychological Knowledge: Current State and Development Prospects. M.: "Institute of Psychology RAS", 2018. P. 671-697.] 
4. Kolyshkina A.V., Olejnik Ju.N. Vozmozhnosti ispol'zovanija metoda indeksa citirovanija v istoriko-psihologicheskom issledovanii // Sovremennaja psihologija: sostojanie i perspektivy issledovanij. Ch. 4. Metodologicheskie problemy istoriko-psihologicheskogo issledovanija: materialy jubilejnoj nauchnoj konferencii IP RAN, 29-29 janvarja 2002 g. / Otv. red. A.L. Zhuravlev. M.: Izd-vo "Institut psihologii RAN", 2002. S. 288-298 [Kolyshkina A.V., Oleinik Yu.N. Possibilities of Using the Citation Index Method in Historical and Psychological Research // Modern Psychology: State and Prospects of Research. Part 4. Methodological Problems of Historical and Psychological Research: Materials of the Jubilee Academic Conference of the IP RAS, January 29-29, 2002 / Ed. ed. A.L. Zhuravlev. M.: "Institute of Psychology RAS”, 2002. P. 288-298.]

5. Kostrigin A.A., Husjainov T.M. Imja L.S. Vygotskogo kak ob'ekt Digital Humanities // Istorija psihologii v licah: Dajdzhest. 2016. № 6. S. 44-66 [Kostrigin A.A., Khusyanov T.M. The name of L.S. Vygotsky as an Object of Digital Humanities // History of Psychology in Persons: Digest. 2016. № 6. P. 44-66.]

6. Kostrigin A.A., Husjainov T.M. Digital Humanities v istorii psihologii (na primere familii V.M. Behtereva) // Cifrovoj uchenyj: laboratorija filosofa. 2018. T. 1. № 1 . S. 160-179 [Kostrigin A.A., Khusyanov T.M. Digital Humanities in the history of psychology (on the example of the name of V.M. Bekhterev) // Digital scientist: laboratory of a philosopher. 2018. Vol. 1. № 1. P. 160-179.]

7. Kostrigin A.A., Mazina K.N. Istoki i aktual'nost' vozniknovenija kognitivnoj psihologii (Digital Humanities v istorii psihologii) // Istorija psihologii v licah: Dajdzhest. 2018. № 3. S. 19-30 [Kostrigin A.A., Mazina K.N. The Origins and Relevance of the Emergence of Cognitive Psychology (Digital Humanities in the history of psychology) // History of Psychology in Persons: Digest. 2018. № 3. P. 19-30.]

8. Kostrigin A.A., Nekrasova A.S., Demeshhuk Je.L. Cifrovaja istorija psihologii: ispol'zovanie ponjatija "bessoznatel'noe" v russkojazychnoj literature // Istorija psihologii v licah: Dajdzhest. 2018. № 3. S. 31-41 [Kostrigin A.A., Nekrasova A.S., Demeshuk E.L. The Digital History of Psychology: the Use of the Concept of "Unconscious" in Russian-language Literature // History of Psychology in Persons: Digest. 2018. № 3. P. 31-41.]

9. Mazilov V.A., Batyrshina A.R. Vozmozhnosti naukometricheskogo podhoda $\mathrm{v}$ istoriko-psihologicheskom issledovanii (na primere problemy voli v otechestvennoj psihologii) // Jaroslavskij pedagogicheskij vestnik. 2016. № 36. S. 63-74 [Mazilov V.A., Batyrshina A.R. Possibilities of the Scientometric Approach in Historical and Psychological Research (with the Problem of will in the Russian Psychology as an Example) // Yaroslavl Pedagogical Bulletin. 2016. № 36. P. 63-74.]

10. Morgun A.N. Naukometricheskoe prostranstvo issledovanij po istorii psihologii: prirosty i izderzhki // Znanie. Ponimanie. Umenie. 2019. № 2. S. 136-146 [Morgun A.N. Scientometric Research Space in the History of Psychology: Increments and Costs // Knowledge. Understanding. Skill. 2019. № 2. P. 136-146.]

11. Nestik T.A., Zhuravlev A.L. Analiz bol'shih dannyh v psihologii i sociogumanitarnyh naukah: perspektivnye napravlenija issledovanij // Psihologicheskij zhurnal.
2019. T. 40. № 6. S.5-17 [Nestik T.A., Zhuravlev A.L. Analysis of Big Data in Psychology and Socio Humanities: Promising Research Areas // Psychological Journal. 2019. Vol. 40. № 6. P. 5-17.]

12. Pisljakov V.V. Bibliometricheskie indikatory v resursah Thomson Reuters // Rukovodstvo po naukometrii: indikatory razvitija nauki i tehnologii / Pod.red. M.A. Akoeva. Ekaterinburg: Izd-vo Ural'skogo universiteta, 2014. S. 75-109 [Pislyakov V.V. Bibliometric Indicators in Thomson Reuters Resources // Guide to Scientometrics: Indicators of Science and Technology Development / Ed. M.A. Akoeva. Ekaterinburg: Publishing House of the Ural University, 2014. P. 75-109.]

13. Pisljakov V.V. Metody ocenki znanija po pokazateljam citirovanija // Sociologicheskij zhurnal. 2007. № 1. S. 128-140 [Pislyakov V.V. Methods for Assessing Knowledge by Citation Indicators // Sociological Journal. 2007. № 1. P. 128-140.]

14. Cherdakova M.M., Kostrigin A.A. Bibliometricheskij analiz publikacij v sbornikah materialov konferencij "Istorija otechestvennoj i mirovoj psihologicheskoj mysli (Moskovskie vstrechi po istorii psihologii)" (2006, 2009, 2016) // Istorija rossijskoj psihologii v licah: Dajdzhest. 2017. № 4. S. 25-37 [Cherdakova M.M., Kostrigin A.A. Bibliometric Analysis of Publications in the Proceedings of the Conferences "History of Russian and World Psychological Thought (Moscow Meetings on the History of Psychology)” (2006, 2009, 2016) // History of Russian Psychology in Persons: Digest. 2017. № 4. P. 25-37.]

15. Burman J.T. What Is History of Psychology? Network Analysis of Journal Citation Reports, 2009-2015 // SAGE Open. 2018. Vol. 8. Is. 1.

16. Coleman S.R., Cola P., Webster S. Characteristics of the System of Production of History-Of-Psychology Literature, 1975-1986 // International Journal of Psychology. 1992. Vol. 27. Is. 1. P. 110-124.

17. Flis I. Digital humanities as the Historian's Trojan Horse: Response to commentary in the special section on digital history // History of Psychology. 2018. Vol. 21. Is. 4. P. 380-383.

18. Green C.D. A digital future for the history of psychology? // History of Psychology. 2018. Vol. 19. Is. 3. P. 209-219.

19. Hirsch J.E. An index to quantify an individual's scientific research output // Proceedings of the National Academy of Sciences. 2005. Vol. 102. Is. 46. P. 1656916572.

20. Krampen $G$. Scientometric trend analyses of publications on the history of psychology: Is psychology becoming an unhistorical science? // Scientometrics. 2016. Vol. 106. Is. 3. P. 1217-1238.

21. Preckel F., Krampen $G$. Development and main topics of psychological giftedness research: A scientometric study of publications between 1980 and 2014 // Psychologische Rundschau. 2016. Vol. 67. Is. 1. P. 1-14.

22. Rushton J.P. A Scientometric appreciation of H.J. Eysenk's contributions to psychology // Personality and Individual Differences. 2001. Vol. 31. Is. 1. P. 17-39.

23. Serova $O$. Scientific metric methods in historical psychological study // International Journal of Psychology. 2000. Vol. 35. Is. 3-4. P. 50. 